\title{
The use of cyclosporin in corticosteroid dependent asthma
}

\author{
M E Coren, M Rosenthal, A Bush
}

\begin{abstract}
Five children with severe asthma requiring at least $10 \mathrm{mg}$ of prednisolone daily were treated with cyclosporin. Three were weaned from prednisolone, but one quickly relapsed. One girl had her steroid dose lowered but suffered unacceptable hirsutism and one child failed to respond. Cyclosporin may be useful in refractory childhood asthma. A prospective study is required to confirm this.

(Arch Dis Child 1997;77:522-523)
\end{abstract}

Keywords: asthma; cyclosporin

Asthma is increasingly recognised as a disease characterised by airway inflammation. Bronchial mucosal biopsy specimens taken from asthmatics show inflammatory infiltrates with prominence of $\mathrm{T}$ cells and eosinophils. ${ }^{1}$ This correlates with disease activity. ${ }^{2}$ Inhibition of T cell function is central to the mechanism of action of corticosteroids in asthma. ${ }^{3}$ Unfortunately, steroids - especially when they are used systemically - have many side effects, of which growth failure is probably the most important in childhood. Steroid sparing agents have been tried including methotrexate, intravenous immunoglobulin, gold, and cyclosporin. ${ }^{4}$

Cyclosporin acts primarily by inhibition of $\mathrm{T}$ helper lymphocyte function and has been shown to be effective in improving lung function and allowing weaning from long term steroids in adult sufferers of asthma. ${ }^{5}$ There is no published work on the use of cyclosporin in childhood asthma.

We present our experience with cyclosporin in five children with severe steroid dependent asthma.

\section{Patients and methods}

Five patients from the the Royal Brompton's paediatric asthma clinic were treated with cyclosporin over a period of 18 months. All were tertiary referrals with poorly controlled

Department of

Paediatric Respiratory

Medicine,

Royal Brompton

Hospital,

Sydney Street,

London SW3 6NP

M E Coren

M Rosenthal

A Bush

Correspondence to: Dr Bush.

Accepted 15 July 1997

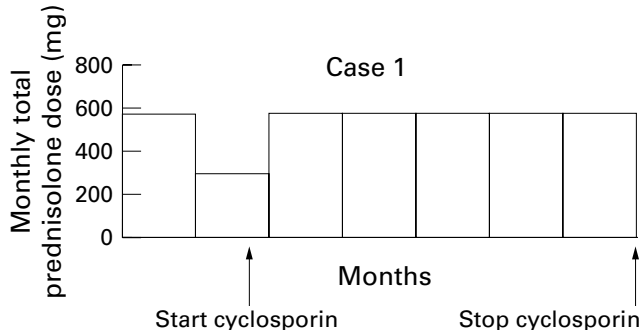

Figure 1 Changes in total monthly dose of prednisolone in case 1 . asthma despite long term systemic steroids - at least $10 \mathrm{mg}$ of prednisolone daily. Table 1 presents the details.

Problems common to all five children were multiple previous attempts to decrease steroid dose and poor school attendance. Cushingoid appearance and loss of linear growth contributed to poor self image. All were on high dose inhaled steroids and had either failed to improve on oral theophylline or were unable to tolerate a high dose due to gastrointestinal side effects.

In each case, before considering an alternative treatment, there was a thorough review of the diagnosis, the minimum investigations being sweat test, immunoglobulins, barium swallow, and $\mathrm{pH}$ probe. Specific allergens were sought on detailed history and tested for with skin prick tests and specific IgE. Where appropriate, allergen avoidance measures were instituted. Other prescribed medication was reviewed and the issue of compliance addressed. A clinical psychologist assisted in all cases.

In each case, cyclosporin was offered as an open therapeutic trial on an individual basis. The need for close monitoring by blood tests was stressed. The cyclosporin dose was 5 $\mathrm{mg} / \mathrm{kg}$ daily. Prednisolone was reduced to the extent allowed by symptoms and lung function monitoring.

MONITORING

Trough whole blood cyclosporin concentration together with electrolytes and creatinine was measured every two to three weeks. The dose was titrated to maintain blood concentrations $80-150 \mathrm{mg} / 1 .^{5}$ Isotope glomerular filtration rate was measured before treatment was started and every three to four months thereafter.

\section{Results}

Table 1 shows the results for each case and figs 1-5 show the steroid dose during the time that the patients were taking cyclosporin.

\section{Discussion}

We report our experience in five children who had a therapeutic trial of cyclosporin. All of the

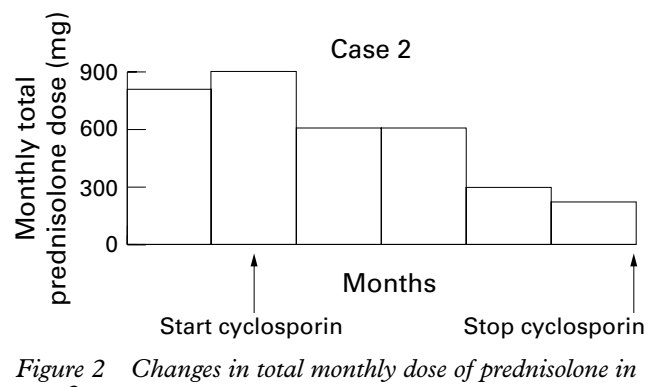
case 2. 
Table 1 Case details with results and side effects of period on cyclosporin

\begin{tabular}{|c|c|c|c|c|c|}
\hline & $\begin{array}{l}\text { Sex (age in } \\
\text { years) }\end{array}$ & $\begin{array}{l}\text { Duration of } \\
\text { continuous } \\
\text { prednisolone } \\
\text { (years) }\end{array}$ & Other medication & Effect of cyclosporin & Side effects \\
\hline 1 & Girl (8) & 2 & $\begin{array}{l}\text { Budesonide } 1 \mathrm{mg} / 12 \text { hours, terbutaline } 5 \mathrm{mg} \\
\text { when necessary }\end{array}$ & No benefit, abandoned after six months & Nil \\
\hline 2 & Girl (15) & 0.8 & $\begin{array}{l}\text { Fluticasone } 1 \mathrm{mg} / 12 \text { hours, terbutaline } 5 \mathrm{mg} \\
\text { when necessary, terbutaline subcutaneous } \\
\text { infusion, salmeterol } 100 \mu \mathrm{g} / 12 \text { hours }\end{array}$ & $\begin{array}{l}\text { Successful reduction in steroid dose, stopped } \\
\text { due to side effect }\end{array}$ & Severe hirsutism \\
\hline 3 & Girl (8) & 3 & $\begin{array}{l}\text { Budesonide } 1 \mathrm{mg} / 12 \text { hours, salbutamol } 5 \mathrm{mg} \\
\text { when necessary, salmeterol } 50 \mu \mathrm{g} / \\
12 \text { hours, theophylline } 200 \mathrm{mg} \text { at night }\end{array}$ & $\begin{array}{l}\text { Initial successful reduction in prednisolone } \\
\text { dose but relapsed within six months }\end{array}$ & Mild hirsutism \\
\hline 4 & Boy (9) & 5 & $\begin{array}{l}\text { Budesonide } 1.5 \mathrm{mg} / 12 \text { hours, terbutaline } \\
1 \mathrm{mg} \text { when necessary, salmeterol } \\
100 \mu \mathrm{g} / 12 \text { hours }\end{array}$ & $\begin{array}{l}\text { Weaned off prednisolone over } 10 \text { months, } \\
\text { major improvement in height and weight } \\
\text { centiles, back at school full time }\end{array}$ & $\begin{array}{l}28 \% \text { decline in glomerular } \\
\text { filtration rate, no change in } \\
\text { creatinine or blood pressure }\end{array}$ \\
\hline 5 & Girl (10) & 5 & $\begin{array}{l}\text { Budesonide } 1.5 \mathrm{mg} / 12 \text { hours, salbutamol } \\
5 \mathrm{mg} \text { when necessary, salmeterol } 100 \mu \mathrm{g} / \\
12 \text { hours, theophylline } 125 \mathrm{mg} / 12 \text { hours }\end{array}$ & $\begin{array}{l}\text { Weaned from prednisolone completely, } \\
\text { major improvement in height/weight } \\
\text { centiles }\end{array}$ & $\begin{array}{l}\text { Transient lymphadenopathy, } \\
\text { mild hirsutism }\end{array}$ \\
\hline
\end{tabular}

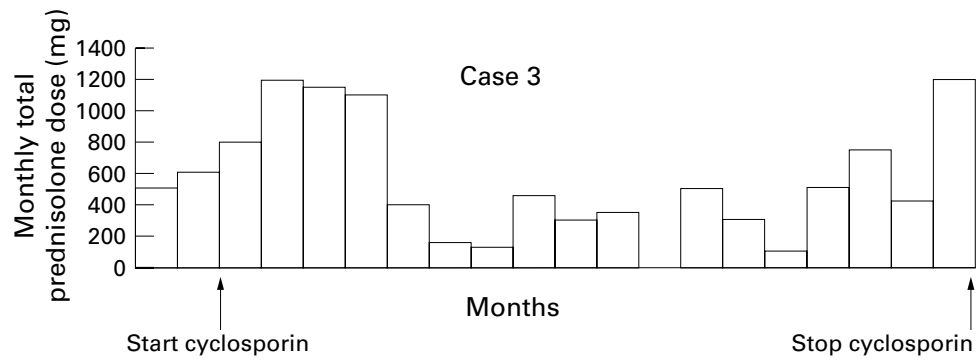

Figure 3 Changes in total monthly dose of prednisolone in case 3.

Figure 4 Changes in total monthly dose of prednisolone in case 4.

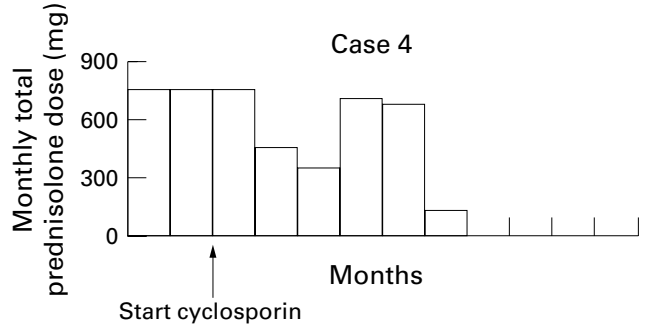

patients described had severe asthma and so were unable to stop taking systemic steroids. These represent the most refractory cases in our asthma clinic: about $1 \%$ of patients over that period of time. They were all steroid responsive, but needed unacceptably high doses to control their symptoms. None was clinically steroid resistant, although in vitro $\mathrm{T}$ cell function was not determined.

We undertook a thorough review of all aspects of management before considering cyclosporin. This is an essential first step because in many patients who are initially referred for a steroid sparing agent there are major issues such as poor compliance. ${ }^{6}$ The finding that almost all trials of steroid sparing agents in asthma show significant

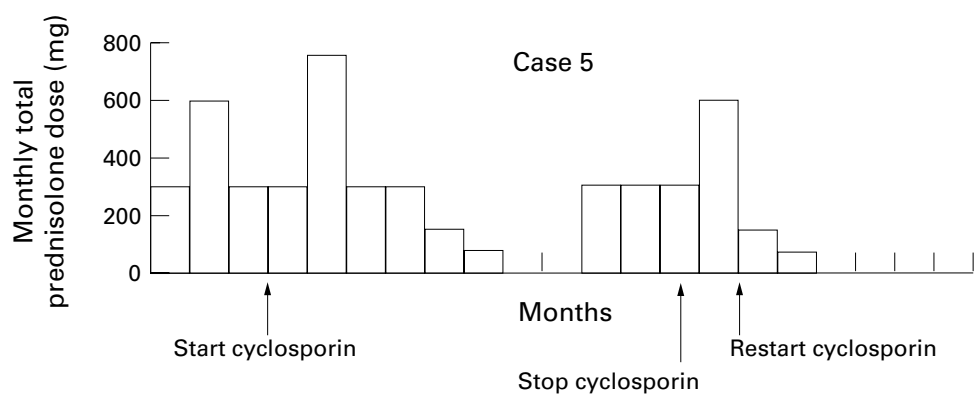

Figure 5 Changes in total monthly dose of prednisolone in case 5. benefit with placebo, as well as the active drug, is important in this respect. ${ }^{4}$ This implies that some patients may be over treated with corticosteroids. In addition, some cases improve spontaneously over time, for example during puberty.

In the cases described, there was clear benefit in three patients, one had temporary, but unsustained benefit, and one did not respond. Three patients complained of hirsutism and this caused one, a teenage girl, to decide to stop taking the drug despite success in lowering her steroid dose and subjective improvement. None of the patients had any rise in creatinine, potassium, or blood pressure over baseline. One patient (case 4) had a $28 \%$ decline in isotope glomerular filtration rate, although no change in creatinine. One patient (case 5) had an episode of tender lymphadenopathy which was resolved when cyclosporin was temporarily stopped.

The experience of cyclosporin in adult asthmatics showed most side effects to be minor and tolerable (hirsutism, paraesthesia, tremor, headaches, mild hypertension)..$^{5}$ The main concern with cyclosporin is renal toxicity. Irreversible damage can occur, but was not reported in any of the trial patients. ${ }^{5}$

Unfortunately, the benefit of cyclosporin was shown to be lost once treatment is stopped. ${ }^{5}$ It is possible that a very low dose over the long term or even an inhaled/nebulised preparation might be beneficial.

In conclusion, we have treated five children, with good responses in three. An open study cannot, however, determine the place of cyclosporin in the management of these most difficult patients. A controlled multicentre trial is needed to generate sufficient suitable cases.

1 Azzawi M, Bradley B, Jeffery PK, et al. Identification of activated T lymphocytes and eosinophils in bronchial biopsies
in stable atopic asthmatics. Am Rev Respir Dis 1990;142:1407-13

2 Corrigan CJ, Kay AB. CD4 T-lymphocyte activation in acute severe asthma. Am Rev Respir Dis 1990;141:970-7.

3 Corrigan CJ, Brown PH, Barnes NC, Tsai JJ, Frew AJ, Kay AB. Glucocorticoid resistance in chronic asthmaperipheral blood T-lymphocyte activation and comparison of T-lymphocyte inhibitory effect of glucocorticoids and cyclosporin A. Am Rev Respir Dis 1991;144:1026-32.

4 cyclosporin A. Am Rev Respir Dis 1991;144:1026-32. Moss RB. Alternative pharmacotherapies
dependent asthma. Chest 1995;107:817-25.

5 Lock SH, Kay AB, Barnes NC. Double blind placebo controlled study of cyclosporin A as a corticosteroid-sparing agent in corticosteroid-dependent asthma. Am F Respir Crit Care Med 1996;153:509-14.

6 Szefler SJ, Kamada AK, Hughes D, Brenner AM, Gelfand EW. Alternative treatments for asthma: assessing the need. f Asthma 1992;29:91-7. 